\title{
FOAM CELLS IN THE STROMA OF CARCINOMA OF THE BODY OF THE UTERUS AND UTERINE CERVICAL POLYPI
}

\author{
BY \\ HILDA R. HARRIS \\ From the Department of Pathology, the Women's Hospital, Liverpool
}

(RECEIVED FOR PUBLICATION JANUARY 18, 1957)

Dubs (1923) and Nunes (1945) each described a case of adenocarcinoma of the body of the uterus in which foam cells were present in the stroma of the neoplasm; these are the only instances recorded in the literature. Foam cells do not seem to have been previously reported as occurring in the stroma of uterine cervical polypi. Two cases of this condition have been observed recently in cervical polypi and prompted an investigation of the frequency of this phenomenon in other gynaecological material. The results of this search are shown in Table $I$.

TABLE I

FOAM CELLS IN MATERIAL EXAMINED

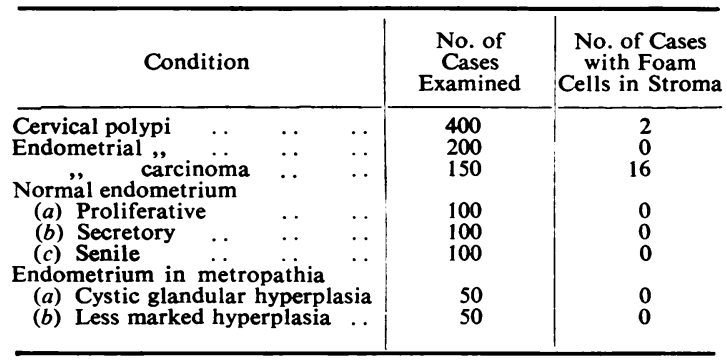

\section{Histological Description}

Adenocarcinoma of Body of Uterus.-Foam cells were found in $11 \%$ of the endometrial carcinomata. All but one of these tumours were well-differentiated adenocarcinomata. The remaining neoplasm showed moderate differentiation, but the foam cells were restricted to those areas in which there was an attempt to form acini. In general, the foam cells occurred in the superficial portions of the growth, where they formed plaques of variable size between the columns of neoplastic cells (Fig. 1). These foam cells usually were packed close together, but in some instances were separated from one another by a small amount of blood or a few connective tissue cells. In certain areas the cells lay in very close proximity to the malignant cells, and because of this their differentiation from the neoplastic cells and from the clear cells of the endometrium was sometimes difficult in sections stained by haematoxylin and eosin (Fig. 2). By using Masson's trichrome stain, the foam cells could be distinguished because their granules stained greenish brown, the granules of the tumour cells stained dark brown, and there were no granules in the clear cells of the endometrium. With this stain it was clear that the foam cells

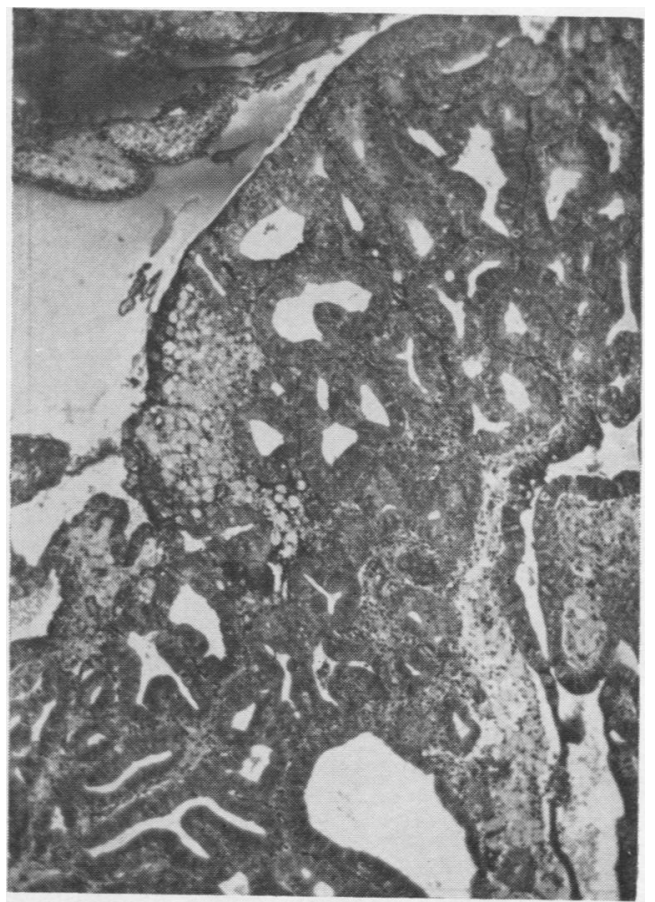

FIG. 1.-Adenocarcinoma of the body of the uterus showing plaques of foam cells between neoplastic cells, $\times 60$. 


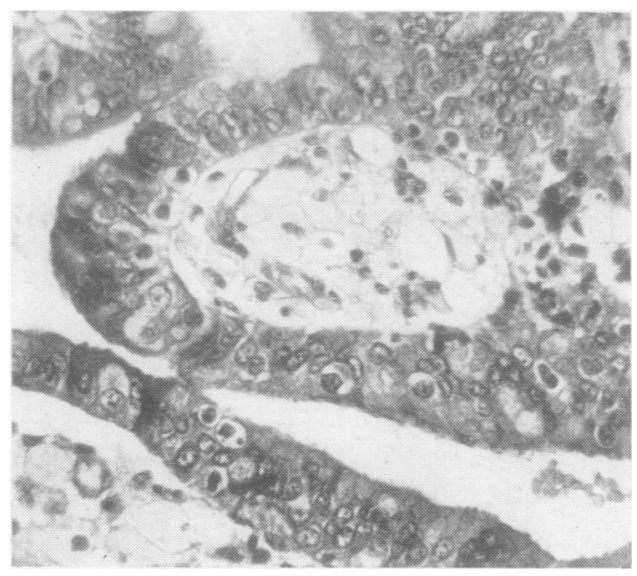

FIG. 2

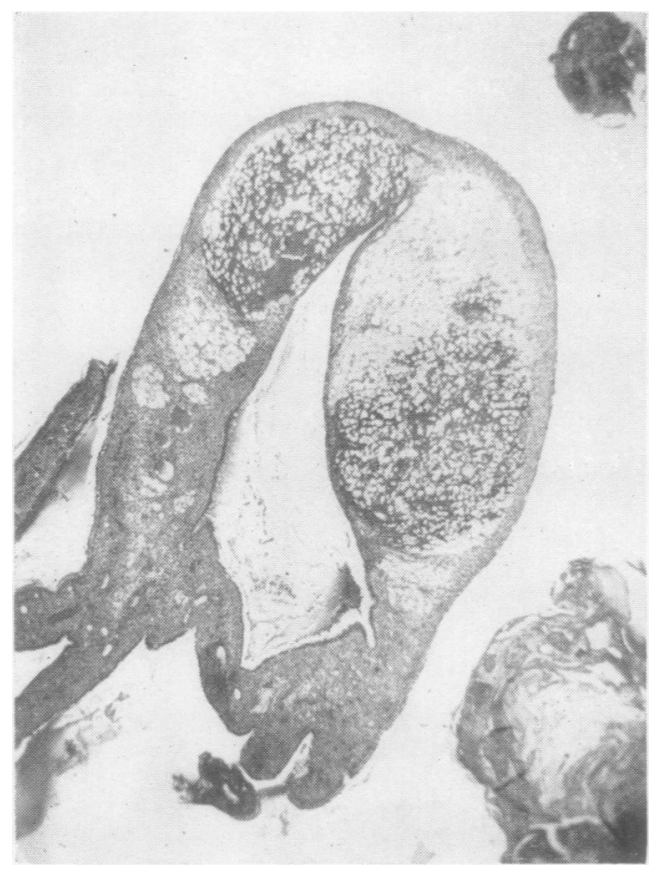

Fro. 3

FIG. 2.-Same tissue as Fig. 1 showing a plaque of foam cells in close proximity to neoplastic cells, $\times 250$.

FIG. 3.-Curettings showing foam cells in stoma of cervical polyp, $\times 20$.

FIG. 4.-Same tissue as previous figure showing details of foam cells in closely packed clearly demarcated masses, $\times 90$.

FIG. 5.-Same tissue as Fig. 4 showing foam cells separated from each other by blood, $\times 90$.

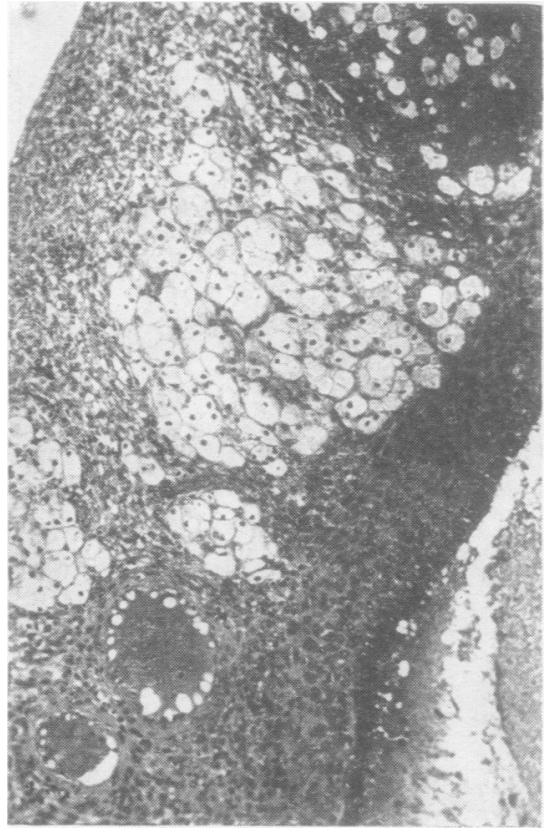

FIG. 4

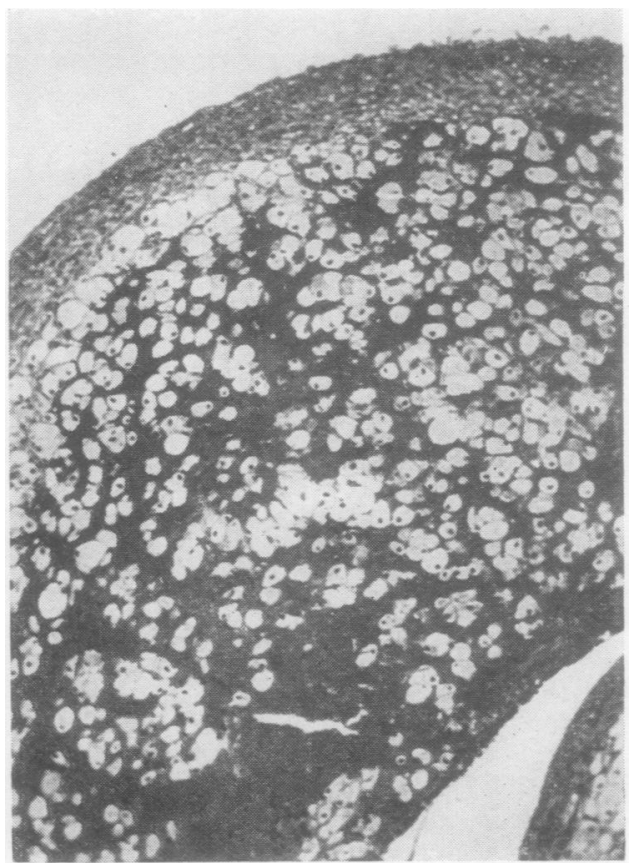

Fic. 5 
sometimes indented the overlying malignant cells but never penetrated between them.

Cervical Polypi.-In the first case most of the core of the polyp was composed of foam cells, which gave the polyp an unusual and arresting histological picture (Fig. 3). The cells were closely packed together to form clearly demarcated masses (Fig. 4) or were separated from one another by a variable amount of blood (Fig. 5). Fibrous tissue or areas of haemorrhage separated the foam cells from the epithelium, which covered the external surface of the polyp. In the second case, the foam cells were not as numerous as in the first one and did not form such a prominent histological feature. Most of them lay in a dilated glandular space situated within the core of the polyp. Haemorrhage had taken place into this space and the foam cells were scattered in small groups throughout it. In one place the continuity of the lining epithelium of the gland had been broken, and beneath this the surrounding connective tissue stroma contained a number of foam cells (Fig. 7).

\section{Minute Histological Structure of the Foam Cells}

The detailed histological features of the foam cells were the same in the cervical polypi and the endometrial carcinomata (Fig. 6). The cells were large and irregular in shape; their nuclei were eccentric in position and had a variable appearance. Some of them were round or oval; they

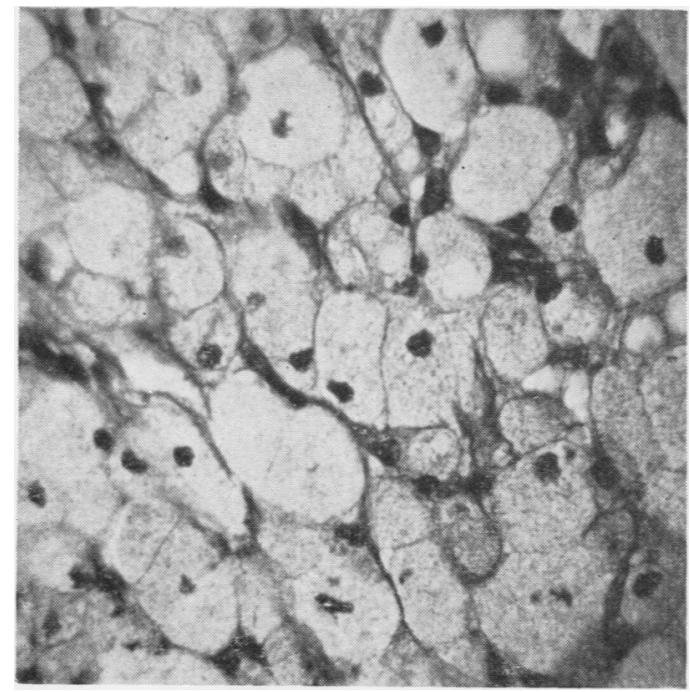

FIG. 6.-Same tissue as Fig. 4 showing morphological features of foam cells, $\times 400$.

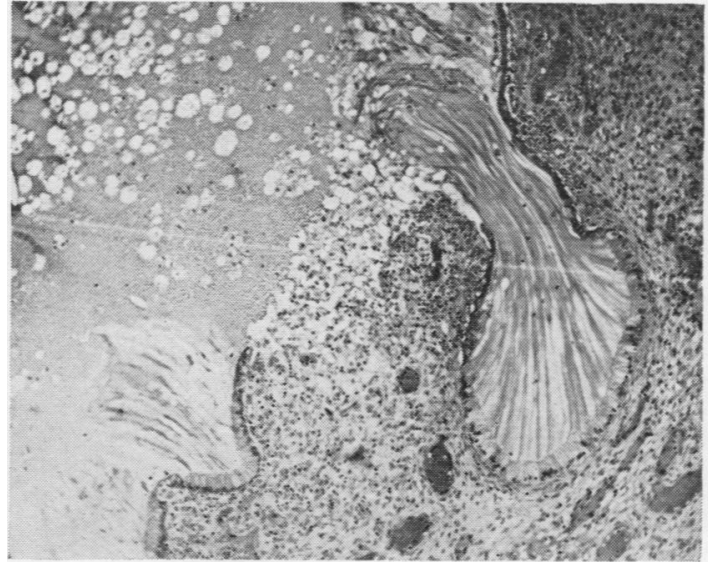

FIG. 7.-Cervical polyp showing a break of continuity of the epithelium of a glandular space in the polyp. Blood and foam cells are present in this area, $\times 60$.

possessed a prominent nucleolus and the chromatin was dispersed evenly in fine granules. In other instances, the nuclei were irregular and showed a variable degree of pyknosis with condensation of their chromatin. In sections stained by haematoxylin and eosin, the cytoplasm had a foamy appearance due to the presence of minute pink granules. The granules stained greenish brown with Masson's trichrome stain, and pink with the periodic-acid-Schiff reaction. Best's carmine stain and the periodic-acid-Schiff reaction before and after treatment with diastase did not show the presence of glycogen. Paraffin sections stained with osmic acid and frozen sections stained with a mixture of Sudan III and IV revealed the presence of black or orange granules respectively in the cytoplasm of the foam cells. Refractile bodies were not seen when paraffin and frozen sections were examined by polaroid screens. Sections stained by Perles' method gave a negative result.

\section{Discussion}

Only two cases of endometrial carcinoma containing foam cells have been recorded (Dubs, 1923 ; Nunes, 1945). The occurrence, therefore, of foam cells in $11 \%$ of endometrial carcinomata is unexpectedly high, but their appearance in cervical polypi is a rare phenomenon.

Foam cells have been described in a variety of tumours, for example, in prostatic carcinoma (Kinoshita, 1920), dermoid cysts (Stewart, 1924), tendon sheath tumours (Garrett, 1924), renal carcinoma (Nathan, 1933), specific nerve sheath tumours (Stout, 1935), sclerosing haemangioma of the brain (Bailey and Ford, 1942), sclerosing 
haemangioma (Dawson, 1948), non-osteogenic fibroma of bone (Lichtenstein, 1952), and in lipoma synovioma and renal adenoma (Evans, 1956). Dawson (1948) considered that foam cells arose as the result of haemorrhage into the tumour. As Perles' reaction is negative, this mechanism will not explain the occurrence of these cells in the cervical polypi or endometrial carcinomata.

Xanthoma cells similar to the foam cells in the cervical polypi are found in the systemic lipidoses. but in these diseases the histological appearance is different, as at the site of the deposition of fat there is an increased fibroblastic activity often associated with giant cell formation. In the first cervical polyp the blood lipids were normal and lesions were not found in other parts of the body.

Aaron and Levine (1954) described an endometrial oil granuloma, which followed a hysterosalpingography. In the cases described in this paper, fatty substances had not been applied locally to the genital tract.

As Gillman (1941) found an increase of stromal fat in metropathia and Black, Heyns, and Gillman (1941) showed that the administration of oestrogens to a castrated woman caused lipid to accumulate in the stromal cells, the foam cells in the cervical polypi and endometrial carcinomata might have been evoked by the action of oestrogens. The patient with the cervical polyp, which contained a large number of foam cells, had taken large amounts of oestrogens, but in the other cases there was no history of the administration of oestrogens. Foam cells were not found in the normal endometrium or in the endometrium of cases of metropathia. It is considered, therefore, that oestrogens are not influential in the production of foam cells.

Wegelin (1947) noted the similarity in appearance of the cells of a granular cell myoblastoma with those found in Gaucher's disease. Sadler and Dockerty (1951) reported one, which arose in the vulva, and Powell (1946) recorded another, in which the ovary contained a secondary deposit. It is unlikely that the first cervical polyp is a granular cell myoblastoma, as the foam cells are situated in the stroma and have a different morphological arrangement to that seen in this tumour.

A common aetiological factor may be responsible for the production of the endometrial clear cells and the foam cells. Feyrter (1949 and 1952) considered that the clear cells formed an endocrine system. Farkas (1952) and Jakobovits (1955) believed that their presence was due to the action of oestrogens. Rotter and Eigner (1951) stated that these cells were degenerative in origin. If the latter concept is accepted both the clear cells and foam cells could be the result of a degenerative process, but if one acknowledges the other opinions the simultaneous appearance of these cells for reasons already stated will be due to different aetiological factors.

It is considered from the above discussion that the cases described in this paper are examples of foam cells occurring in tumours. There is insufficient evidence to explain the processes which give rise to these cells.

\section{Summary}

Foam cells were found in the stroma of only two cervical polypi out of a series of 400 cases.

In a series of 150 endometrial carcinomata foam cells were present in the stroma of 16 cases.

Foam cells were not demonstrated in a series of 200 endometrial polypi, in the normal endometrium, or in the endometrium of cases of metropathia.

The various aetiological factors which could be concerned in the production of foam cells in the cervical polypi and the endometrial carcinomata have been discussed. It was considered that there was insufficient knowledge to explain the processes which are responsible for the development of these cells.

I wish to thank the surgeons of the Women's Hospital. Liverpool, for most of the material, and $\mathrm{Mr}$. Corbett and Dr. Pantin, who provided me with material from an endometrial carcinoma which contained foam cells.

\section{REFERENCES}

Aaron, J. B., and Levine, W. (1954). Amer. J. Obstet.. 68, 1594 Bailey, O. T., and Ford, R. (1942). Amer. J. Path., 18, 1

Black, J., Heyns, O. S., and Gillman, J. (1941). J. clin. Endoc\%. 1 547

Dawson, E. K. (1948). Edinb. med. J., 55, 655

Dubs, I. (1923). Zbl. allg. Path. path. Anat., 34, 145.

Evans, R. Winston (1956). Histological Appearances of Tumours. pp. 42, 92, and 661. Livingstone, Edinburgh and London.

Farkas, K. (1952). Acta morph. hung., 2, 253.

Farkas, K. (1952). Acta morph. hung., 2, 253. 316,435

Feyrter, F. (1949). Virchows
-(1952). Ibid., 321, 134.

Garrett, C. A. (1924). Arch. Surg. (Chicago), 8, 890.

Gillman, J. (1941). S. Afr. J. med. Sci., 6, 59.

Jakobovits, A. (1955). Z. Geburtsh. Gynäk., 142, 313.

Kinoshita, M. (1920). Z. Urol., 14, 193.

Lichtenstein, L. (1952). Bone Tumors, 1st ed., p. 95. Mosby, St. Louis.

Nathan, H. (1933). Z. urol. Chir., 37, 337.

Nunes, M. A. (1945). Amat. lusit., 4, 461.

Powell, E. B. (1946). Arch. Path. (Chicago), 42, 517.

Rotter, W., and Eigner, J. (1951). Excerpta med. (Amst.), Sect. v, 4, 68. Sadler, W. P., and Dockerty, M. B. (1951). Amer. J. Gynec. Obstel., $61,1047$.

Stewart, M. J. (1924), Brit. med. J., 2, 893.

Stout A. P (1935) Amer J Cancer, 24, 751.

Wegelin. C. (1947). Schweiz. Z, allg. Path. Bakt., 10, 631. 